\title{
Distribution and habitat preferences of the genus Biomphalaria (Gastropoda: Planorbidae) in Cuba
}

\author{
Antonio Alejandro Vázquez Perera/ ${ }^{+}$, Jorge Sánchez Noda, Yosvania Hevia Jiménez \\ Laboratory of Malacology, Institute Pedro Kourí, Autopista Novia del Mediodía km 6 1², PO Box 601, Marianao 13, Havana, Cuba
}

A study was carried out to determine the distribution and habitat preferences of several species of the genus Biomphalaria. Samples were taken at 350 freshwater locations in Cuba. Three species of Biomphalaria (Biomphalaria havanensis, Biomphalaria helophila and Biomphalaria pallida) were recorded based on their distribution. Of the three species, B. havanensis has the weakest distribution because it was identified in only one locality. The other species, B. helophila and B. pallida, are abundant in rivers and dams and have large populations in Cuba. However, the only species that appears to occur in ecosystems shared with thiarids is B. pallida, possibly due to recent introduction of thiarids, but always in fewer numbers. Here we discuss the possibility of these species to act as intermediary hosts of Schistosoma mansoni in Cuba over the basis of occurrence in natural and anthropic habitats.

Key words: Biomphalaria - snail - intermediary host - schistosomiasis - ecology

Of the small species richness found in Cuban freshwater malacological fauna, the family Planorbidae is the best represented with 11 species. Three of these species belong to the genus Biomphalaria (Pointier et al. 2005). The Cuban species of this genus are Biomphalaria havanensis (Pfeiffer, 1839) (type locality: Havana, Cuba), Biomphalaria helophila (d'Orbigny, 1835) (type locality: Callao, Peru) and Biomphalaria pallida (CB Adams, 1846) (type locality: Jamaica). These species have a flattened and sinister shell that usually does not exceed $10 \mathrm{~mm}$ in diameter (Yong 1998) (Fig. 1). Other species of Biomphalaria, including Biomphalaria orbigny, Biomphalaria schrammi, Biomphalaria peregrina and Biomphalaria obstructa, were previously thought to inhabit Cuba, but this now known to be incorrect (DeJong et al. 2001).

The genus Biomphalaria is well known because of the role some species have in the transmission of schistosomiasis (Perera 1996, Yong 1998), which is considered to be one of the most important tropical diseases in the world (WHO 2002). In the western hemisphere, the main species related to this disease is Biomphalaria glabrata (Paraense 2001). In America, schistosomiasis is produced by the parasite Schistosoma mansoni. In Cuba, however, there have not been reports of either the parasite or the main intermediary host snail (Pointier et al. 2005), although the occurrence of related species from the same genus creates a high risk of introduction of this disease.

Determining the distribution of Cuban Biomphalaria species provides information of possible areas where sporadic outbreaks of schistosomiasis could appear. Although these species may establish themselves in many types of ecosystems, they are generally associated with

+ Corresponding author: antonivp@ipk.sld.cu

Received 21 May 2009

Accepted 19 October 2009 certain habitats. If sufficient ecological data is gathered and pooled, a powerful tool to prevent and control possible outbreaks is obtained. This study aims to assess future possible outbreaks by gathering distribution information for these species.

\section{MATERIALS AND METHODS}

Although taxonomic problems have been found with some species of Biomphalaria, here we refer to $B$. havanensis and $B$. pallida after the discussion presented by Yong et al. (2001). Identification of the species was made using both conchological and anatomical (reproductive system) characteristics.

From the database of the Laboratory of Malacology at the IPK, 350 locations distributed throughout Cuba were analysed. In each locality, the presence or absence of Biomphalaria was verified and the main characteristics of the ecosystems on which they were established were recorded. These data were previously recorded in field samplings during malacological surveys decades ago. Each locality was georeferenced using GIS MapInfo 8.5. In this way the distribution of each species of the genus Biomphalaria in Cuba was obtained.

The ecosystems were classified as natural, seminatural or anthropic, according to an analytic index using human access as the measure (Table). Each species was compared in relation to the ecosystem type by Kruskal-Wallis ANOVA (differences considered significant at $\mathrm{p}<0.05$ ) and related to the presence of some of the cohabitating freshwater snail families by a canonical correspondence analysis (Ter-Braak 1986). All statistical tests were done using the software STATISTICA 6.0y MVSP 3.12h.

\section{RESULTS}

Distribution maps - Distribution of each species of Biomphalaria is shown in Fig. 2. The best-established species is $B$. helophila with populations distributed from the Guanahacabibes Peninsula (western-most tip of Cuba) to the eastern side of Cuba and the Isle of Youth. 
TABLE

Classification of the ecosystems according to the access by humans

\begin{tabular}{lc}
\hline Classification & Ecosystems \\
\hline Natural & stream, seasonal pond, seasonal brackish pond, permanent pond, lake, coastal lagoon, river, flooded terrain \\
Semi natural & rice field, artificial pond, dam \\
Anthropic & drainage channel, quarry, ditch \\
\hline
\end{tabular}

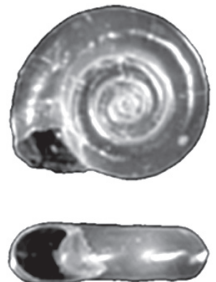

A

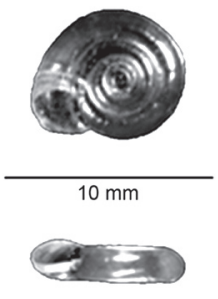

B

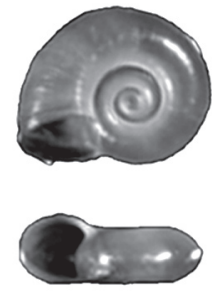

C
Fig. 1: Cuban species of Biomphalaria. A: Biomphalaria havanensis; B: Biomphalaria helophila; C: Biomphalaria pallida.

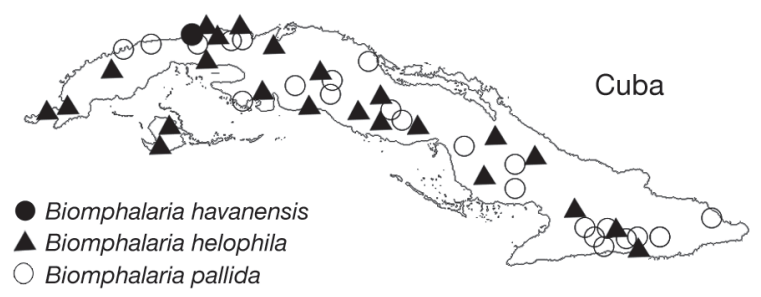

Fig. 2: distribution maps of Cuban species of Biomphalaria.

B. pallida has several populations in the Eastern Region of Cuba, especially in Havana, with random populations in the other provinces. The species with the weakest distribution is $B$. havanensis with only one population occurring in the country.

Habitat preferences of Biomphalaria - The species of Biomphalaria showed significant differences (K-W, $\mathrm{p}=0.0017)$ within the habitat types where their populations were found. Fig. 3 shows the distribution patterns of certain populations of Biomphalaria in each ecosystem type. The greatest number of populations is found mainly in rivers, dams and artificial ponds. Other ecosystems, like seasonal ponds, streams and flooded terrains, were less significant.

Fig. 4 shows that B. helophila and B. pallida are more abundant in natural habitats, although $B$. helophila is more evenly distributed among all habitat types while $B$. pallida is rarely observed in anthropic ecosystems. The population of $B$. havanensis was found in a site where there is a large amount of human activity.

Relation of Biomphalaria populations with other snail families and habitat types - Fig. 5 shows the ca-

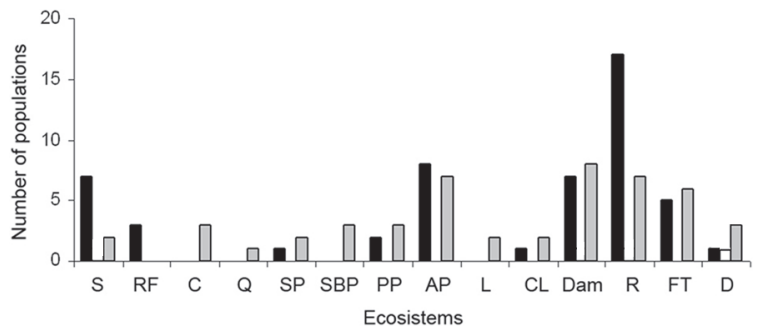

- Biomphalaria pallida 口Biomphalaria havanensis 口Biomphalaria helophila

Fig. 3: distribution of the three species of Biomphalaria in different freshwater ecosystems in Cuba. AP: artificial pond; C: drainage channel; CL: coastal lagoon; D: ditch; FT: flooded terrain; L: lake; PP: permanent pond; Q: quarry; SP: seasonal pond; R: river; RF: rice field; S: stream; SBP: seasonal brackish pond.

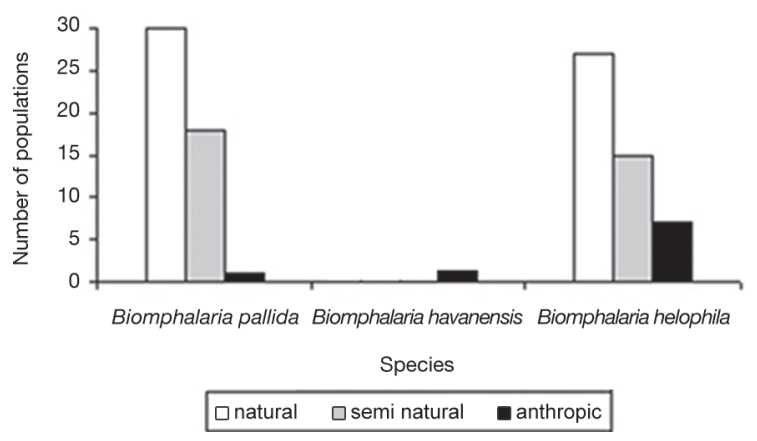

Fig. 4: most common types of habitats for each species of Biomphalaria.

nonical correspondence analysis where the three species of Biomphalaria are associated with ecological variables. $B$. havanensis is the species least associated with the other freshwater snail families, but is closely related with ditch ecosystems. Rivers and rice fields are habitats where hydrobiids and thiarids usually occur and are positively related with $B$. pallida. Permanent and seasonal ponds as well as flooded terrains correlated with $B$. helophila populations. This species was the only Biomphalaria occurring in brackish water ponds.

Some families of freshwater snails (Lymnaeidae, Physidae and Ampullariidae) are negatively associated with permanent and seasonal ponds and flooded terrains and seem to be more common in streams where the only species of Biomphalaria that appears to be well established is 
B. pallida. The dams are a suitable habitat for $B$. helophila and $B$. pallida and especially for every planorbid, including some species of Drepanotrema. This may account for the weak relation $B$. helophila and B. pallida have with the remaining habitats. In addition, the other families seem to be primarily related to other types of habitats.

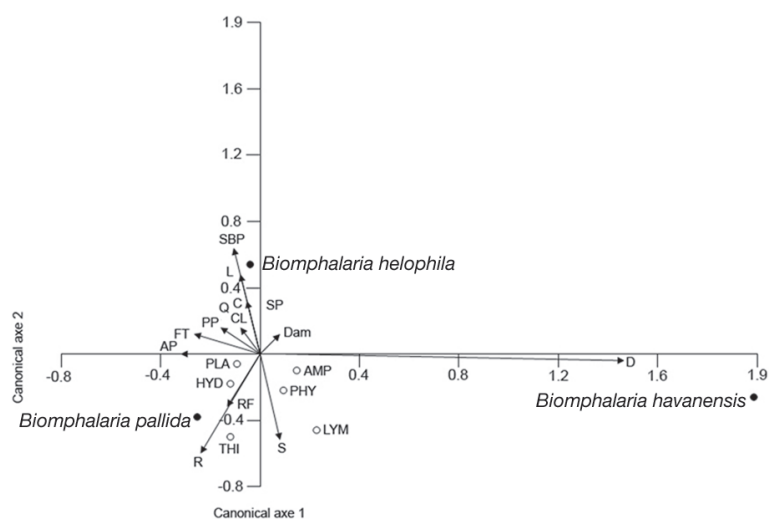

Fig. 5: scatter-plot of the canonical correspondence analysis between the species of Biomphalaria, some freshwater snail families (AMP: Ampullariidae; HYD: Hydrobiidae; LYM: Lymnaeidae; PHY: Physidae; PLA: Planorbidae; THI: Thiaridae) and the main ecosystems on which they are found (AP: artificial pond; C: drainage channel; CL: coastal lagoon; D: ditch; Dam: dam; FT: flooded terrain; L: lake; PP: permanent pond; Q: quarry; R: river; RF: rice field; S: stream; SBP: seasonal brackish pond; SP: seasonal pond).

\section{DISCUSSION}

Although Cuba is the locality for B. havanensis, only one population has been found in nature and it is the least represented species of the genus (Yong et al. 1997). This species has also been reported in other Caribbean areas, such as the Dominican Republic and Venezuela (Yong et al. 2001). The two best represented species, $B$. helophila and B. pallida, are well distributed in most of the freshwater bodies of the country, especially those found in stable ecosystems (Perera 1996). All these species are generally associated with aquatic vegetation and may reach high densities if the conditions are suitable (Yong et al. 2001).

There seems to be a certain similarity between the ecological requirements of $B$. helophila and B. pallida because they are generally found in similar ecosystems. However, it has been observed that each of the three species of Biomphalaria dominates indistinctively within different specific habitats. The three species only seem to share the ditch ecosystem to a similar degree. The mechanism by which these species may colonise ponds, lakes and swamps in other regions of Central America and the Caribbean has been previously described (Pointier et al. 2005).

The presence of B. helophila and B. pallida primarily in natural ecosystems argue against their playing a large role in the transmission of schistosomiasis in Cuba. The ecosystems where they occur are not highly populated. Perhaps the risk would increase in habitats like dams and farming flooded terrains occurred where human activity is higher. The only population of $B$. havanensis related its distribution with urban ecosystems and hence we cannot ensure a strong association with this type of habitat or any other co-occurring snail families. This fact makes us believe that this species could be the main intermediary host following an introduction of $S$. mansoni to Cuba if further similar populations are found. This species has been suggested as a potential host of schistosomiasis in some areas of the region (Vidigal et al. 2001).

Only one species, B. pallida, seems to maintain a positive relation with thiarids, while the remaining two species are negatively associated with this family. Thiarids, especially Melanoides tuberculata, have been used as biological control agents over some populations of Biomphalaria in Cuba (Perera et al. 1990, Perera 1996) and in some areas of the Caribbean (Pointier et al. 1991, 1994, Pointier \& Jourdane 2000, Pointier \& David 2004). It is possible that the coexistence of both species is due in many cases to the recent arrival of the thiarids, which are highly invasive species. The abundance of the species of Biomphalaria is much lower in many locations compared to M. tuberculata or Tarebia granifera (another competitive thiarid), according to previous studies (Vázquez \& Gutiérrez 2007).

In spite of this, control techniques using competitor species that lead to a decrease in the population of schistosomiasis, intermediary hosts remain one of the best ways to prevent and control this disease. Furthermore, introduction of competitor species does not cause great damage to the ecosystem (Perera \& Walls 1996). Knowing the distribution patterns of the genus Biomphalaria in Cuba and the different types of habitats they colonise improves the strategies aimed to control their population.

\section{REFERENCES}

De Jong RJ, Morgan JA, Paraense WL, Pointier JP, Amarista M, AyehKumi PF, Babiker A, Barbosa CS, Brémond P, Canese AP, Pererira C, Dominguez D, File S, Gutiérrez A, Incani RN, Kawano T, Kazibwe F, Kpikpi J, Lwambo NJ, Mimpfoundi R, Njiokou F, Poda JN, Sene M, Velásquez LE, Yong M, Adema C, Hofkin BV, Mkoji GM, Loker ES 2001. Evolutionary relationships and biogeography of Biomphalaria (Gastropoda: Planorbidae) with implications regarding its role as host of the human bloodfluke, Schistosoma mansoni. Mol Biol Evol 1: 189-194.

Paraense WL 2001. The schistosome vectors in the Americas. Mem Inst Oswaldo Cruz 96 (Suppl.): 7-16.

Perera G 1996. Ecologie des mollusques d'eau douce d'intérêt médical et vétérinaire à Cuba, $\mathrm{PhD}$ Thesis, Perpignan, $105 \mathrm{pp}$.

Perera G, Walls JG 1996. Apple snails in the aquarium, TFH Publications, New Jersey, $121 \mathrm{pp}$.

Perera G, Yong M, Ferrer JR, Arrianda C, Amador O 1990. Effectiveness of three biological control agents against intermediate hosts of snail-mediated parasites in Cuba. Malacological Review 23: 47-52.

Pointier JP, David P 2004. Biological control of Biomphalaria glabrata, the intermediary host of schistosomes, by Marisa cornuarietis in ponds of Guadalupe: long-term impact on the local snail fauna and aquatic flora. Biol Control 29: 81-89.

Pointier JP, Incani RN, Balzan C, Chrociechowski P, Prypchan S 1994. Invasion of the rivers of the littoral central region of Venezuela by 
Thiara granifera and Melanoides tuberculata (Mollusca: Prosobranchia: Thiaridae) and the absence of Biomphalaria glabrata, snail host of Schistosoma mansoni. Nautilus 107: 124-128.

Pointier JP, Jourdane J 2000. Biological control of the snail hosts of schistosomiasis in areas of low transmission: the example of the Caribbean area. Acta Trop 77: 53-60.

Pointier JP, Theron A, Imbert-Estabelet D, Borel G 1991. Eradication of a sylvatic focus of Shistosoma mansoni using biological control by competitor snails. Biol Control 1: 244-247.

Pointier JP, Yong M, Gutiérrez A 2005. Guide to the freshwater molluscs of Cuba, Conchbooks, Hackenheim, 120 pp.

Ter-Braak JF 1986. Canonical correpondence analysis: a new eigenvector technique for multivariate direct gradient analysis. Ecology 67: 1167-1679.

Vázquez AA, Gutiérrez A 2007. Ecología de moluscos fluviales de importancia médica y veterinaria en tres localidades de La Habana. Rev Cub Med Trop 59: 149-153.
Vidigal T, Caldeira R, Simpson A, Carvalho O 2001. Identification of Biomphalaria havanensis and Biomphalaria obstructa populations from Cuba using polymerase chain reaction and restriction fragment length polymorphism of the ribosomal RNA intergenic spacer. Mem Inst Oswaldo Cruz 96: 661-665.

WHO - WORLD HEALTH ORGANIZATION 2002. Prevention and control of schistosomiasis and soil-transmitted helminthiasis. WHO Technical Report Series 912, Geneva, 57 pp.

Yong M 1998. Biosystématique des mollusques d'eau douce d'intérêt médical et vétérinaire à Cuba, $\mathrm{PhD}$ Thesis, Perpignan, $104 \mathrm{pp}$.

Yong M, Gutiérrez A, Perera G, Durand P, Pointier JP 2001. The Biomphalaria havanensis complex (Gastropoda: Planorbidae) in Cuba: a morphological and genetic study. J Molluscan Stud 67: 103-111.

Yong M, Pointier JP, Perera G 1997. The type locality of Biomphalaria havanensis (Pfeiffer, 1839). Malacological Review 30: 115-117. 